other considerations, lead us to give the preference to this form. The advantage is not, however, great, and disappears when we have to distinguish cases where we must substitute $n^{3}$ for $n^{4}$. The reason why I prefer Rydberg's form at present lies in the fact that it adapts itself better to bring out the regularities as well as the irregularities of distribution of the lines independently of any special form of equation. To show this we may write Rydberg's equation in the form

$$
\frac{n+\mu}{\sqrt{\mathrm{B}}}=\frac{\mathrm{I}}{\sqrt{\mathrm{A}-\mathrm{N}}} .
$$

The convergence frequency, $\mathrm{A}$, may be determined by some graphical process if a sufficient number of lines have been observed, and the law of formation of a spectroscopic series may therefore be expressed as follows :

The inverse square roots of the difference between the convergence frequency and the frequency of successive lines are very approximately in arithmetical progression. If we wish to determine how far any series conforms to this law, we may in the first place calculate the right-hand side of the above expression with some approximate value of A. Systematic deviations from arithmetical progression may then be corrected by a small change, $\delta \mathrm{A}$ producing a difference $\frac{\delta \mathrm{A}}{\sqrt{(\mathrm{A}-\mathrm{N})^{3}}}$ in the numbers. But it will nearly always be found that there are some outstanding deviations which cannot be corrected for in this way. The value of $B$ is found at once from the arithmetical progression successive numbers differing by $\frac{\mathrm{I}}{\sqrt{\mathrm{B}}}$. I have found this method of testing the series and

calculating the constants very useful, and hope on some other occasion to return to it.

ARTHUR SCHUSTER.

\section{UNDULATIONS IN LAKES AND INLAND SEAS DUE TO WIND AND ATMOSPHERIC PRESSURE.}

I T is generally known that considerable variation takes place in the level of the surface of the water in lakes and inland seas owing to the effect of the wind in gales and during stormy weather. The minor undulations which occur at more regular intervals have not attracted the same observation, and the cause of these is still a matter of some uncertainty. In the large lakes in America, fishermen and boatmen have learnt to regard these undulations as storm warnings ; and on the coasts of Europe, the rollers which break on the shore in calm weather are looked upon as indicative of a coming storm. Thus, in the Bay of Biscay frequently during the autumn and winter in calm weather a heavy sea gets up and rolls in on to the coast four-and-twenty hours before the gale which causes it arrives, and of which it is the prelude. In this case the wave action, generated on the other side of the Atlantic by the wind, travels at much greater rate than that of wind, and thus gives timely warning of the coming storm. So also on the opposite side of the Atlantic, on the coast between North Carolina and Cape Hatteras, the currents, which are there largely governed by the wind, begin to run strongly several hours in advance of the wind which causes them. In summer a change of the current from north-east to south-west is always taken as a true indication of an approaching north-east wind.

The effect of gales on tideless seas and lakes is so marked as to cause frequently considerable inconvenience and anxiety to mariners. Thus, in the Caspian Sea a gale will raise the water on one side 6 feet and depress it on the other as much, making a total difference of level of 12 feet. $^{1}$ 1 "Tidal Rivers," cbap. v. (Longmans, Green, and Co.). NO. I 475 , vOL. 57$]$
In the Baltic easterly gales will alter the level upwards of 8 feet. In Lake Erie ${ }^{1}$ depressions and elevations of from 2 to 4 feet are common, while occasionally heavy gales have produced a difference of level of upwards of I 5 feet. Almost invariably about the time of the spring equinox strong gales occur from the east, raising the water from 4 to 6 feet at the west end of the lake, and depressing it to a similar extent at the east end, making a total difference of from 8 to 12 feet. About the time of the autumn equinox gales from the west lower the water 7 to 8 feet at the west side, and raise it 5 to 8 feet at the east end, making a difference from the normal level of from 12 to 16 feet. An illustration is given by Mr. Blunt, the engineer, who reported on the subject for the United States Commission as to the way in which the navigation of the lakes and of the rivers connected with them is affected by storms acting on the surface of the water. A steamer which had to make a trip down the river found the water at the pier from which she started, five miles from the mouth, had receded to $7 \frac{1}{2}$ feet below the normal level. In the river, flats were showing where a few days before they had found 8 feet of water. In the middle of the bay a large dredger was aground where there ought to have been 17 feet of water.

In addition to these larger oscillations, there are also minor undulations which occur at varying intervals, the largest period for a complete oscillation not exceeding half an hour, and the alteration in the level of the water not more than from three to four inches. The phenomena had been noted by Duillier on the Swiss Lakes in the middle of the last century, the name locally given to them being Seiches. In 1804 Vaucher also investigated the

\section{UNDULATIONS AT MOUTH OF HUMBER RIVER. Sept $28^{\mathrm{m}} 1896$}

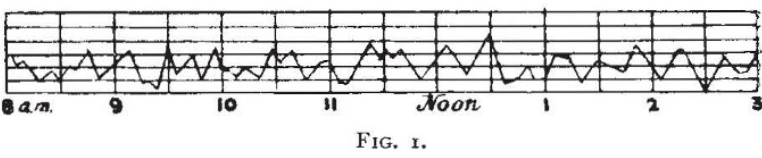

matter and published an account of his researches, his experience being that they were common to all the lakes ; that they recurred at all seasons of the year, but most frequently in spring and autumn, the greatest oscillation, however, occurring in the summer; and that the intervals between the oscillations did not exceed twenty to twentyfive minutes, and more frequently less.

A few years since the writer had occasion to investigate the oscillations which took place in one of the Norfolk Broads, and which were taken as showing that the water was tidal. It was found that variations of from half an inch to two and three inches in the level of the water took place periodically, and at times when the atmosphere was calm. Observations spread over a considerable time proved that these undulations were not coincident with the rise and fall of the tides, and that they had no direct connection with the ebb and flow in the river with which this Broad was connected.

The character of the undulations on Lake Superior has been investigated by Mr. Napier Denison, and the results communicated to the Canadian Institute in February I 897 , in a paper entitled "The great lakes as a sensitive barometer." For the purpose of tracing these curves Mr. Denison had two self-tecording gauges constructed, one being fixed at the mouth of the river Humber, and the other at the Burlington Canal. The results of one day's reading at the mouth of the Humber are shown in Fig. I, which is sufficient generally to illustrate the result of the readings obtained, and as showing the rapid undulations upon the lakes during light winds and fine weather preceding a severe storm. (The divisions in the above 1 Report of Deep Waterways Commission, U.S.A. (Washington, 1897). 
diagram represent inches.) The undulations generally vary from three to four inches at intervals of from fourteen to eighteen minutes. The centre of the storm which caused these oscillations was over the State of Florida, I 300 miles distant. This storm centre travelled slowly but directly to the lake region, where it caused a severe gale. These lake undulations are found to be of a more sensitive character than the indications of approaching storms given by the barometer. Mr. Denison is of opinion that these oscillations are due to the action of atmospheric waves or billows in passing over the surface of the lakes, which tend to form minute undulations upon the surface corresponding in length to these billows, and becoming magnified when they reach narrower and shallower portions, until finally they assume the proportions recorded upon the instrument.

Attention has also recently been directed to the minor undulations which occur in tidal waters by Mr. W. Bell Dawson, the Government surveyor engaged in the tidal survey of the Gulf of St. Lawrence, in a paper presented to the Royal Society of Canada in May I895, entitled "Notes on secondary undulations." These undulatory disturbances in the regular rise and fall of the tides in the Gulf of St. Lawrence are plainly marked on the records of the self-registering tide gauges, their magnitude being in proportion to the amplitude of the tides. Similar undulations have also been observed in the Mediterranean at Malta. The illustration (Fig. 2,

Zoologists who propose to be present should communicate with Prof. Hickson, F.R.S., at the Owens College, Manchester.

Mr. Thomas H. Blakesley has resigned his seat at the Council Board of the Physical Society. He is, therefore, no longer hon. secretary of that Society.

IT has been decided to publish, under the auspices of the Physical Society and the Institution of Electrical Engineers, a series of abstracts of English, American, and foreign papers on physics and electrical engineering.

The Harvard University, Cambridge, Mass., has invited Dr. Hans Reusch, Director of the Norwegian Geological Survey, to give two series of lectures-one on "Vulcanism," the other on "the Geology of Scandinavia." Dr. Reusch will return to Christiania in Tune.

AT the annual meeting of the Royal Microscopical Society on Wednesday, January 19 , the President, after reviewing the progress in microscopical science during the past year, gave for his address an account of the manner in which achromatic doublets and triplets were practically calculated. The President explained by drawings on the blackboard the general scope of the paper, which, owing to its mathematical treatment, could not be read verbatim.

THE death is announced of Dr. Samuel Newth, author of "A First Book of Natural Philosophy," which has had a very large sale, and "The Elements of Mathematics, including Hydrostatics." In 1855 Dr. Newth became professor of mathematics and ecclesiastical history in the New College, St. John's Wood, and succeeded Dr. Halley as principal of the College in 1872 , retiring from this post in I889.

WE learn from Science that, at the meeting of the Corporation of Yale University on January $\mathrm{I}_{3}$, Prof. O. C. Märsh, professor of palæontology, formally presented to the University the valuable scientific collections belonging to him,

taken from Mr. Dawson's paper) shows the character of these undulations at high and low water in part of the Bay of Fundy, on tides having an amplitude of from I7 to 19 feet.

W. H. WHEELER.

\section{NOTES.}

THE meeting of the Royal Society on Thursday, February 24, will be devoted to a discussion of the "scientific advantages of an Antarctic Expedition." The debate will be opened by Dr. John Murray, F.R.S., of the Challenger.

Prof. L. Cremona, professor of higher mathematics in the University of Rome, has been elected a Correspondant of the Paris Academy of Sciences, in succession to the late Prof. Sylvester.

H.R.H. The Prince of Wales has been graciously pleased to accept the post of Patron of the fourth International Congress of $Z$ oology, to be held at Cambridge next August.

A meeting will be held in Manchester on February 16 to take into consideration such steps as may seem desirable to assist the Executive Committee in making the Zoological Congress this year thoroughly successful. The Literary and Philosophical Society have put their rooms at the disposal of the meeting, and Mr. J. Cosmo Melvill will take the chair at 5 o'clock on that day. This appears to us to be an excellent movement, and one worthy of imitation in other large centres.

NO. 1475 , VOL. 57$]$ now deposited in the Peabody Museum. These collections, six in number, are in many respects the most extensive and valuable of any in America, and have been brought together by Prof. Marsh, at great labour and expense, during the last thirty years. They include collections of vertebrate fossils, fossil footprints, invertebrate fossils, recent osteology, American archæology and ethnology, and minerals. The palæontological collections are well known, and were mainly secured by Prof. Marsh during his explorations in the Rocky Mountains. They include most of the type specimens he has described in his various publications. The collection of osteology and that of American archæology are also extensive and of great interest. The present value of all these collections makes this the most important gift to natural science that Yale has yet received. The President and Fellows of Yale accepted Prof. Marsh's gift by a unanimous vote, and expressed their high appreciation of his generosity to the University.

AMONG the papers to be read at forthcoming meetings of the Society of Arts are the following:-Ordinary meetings (Wednesday evenings, at eight o'clock): February 23, children's sight, by Mr. R. Brudenell Carter; March 2, kites, their theory and practice, by Captain B. F. S. Baden-Powell; March 9, Linde's method of producing extreme cold and liquefying air, by Prof. J. A. Ewing, F.R.S. ; March 16, the recent history of paper-making, by Mr. Clayton Beadle ; March 23, the preparation of meat extracts, by Mr. C. R. Valentine ; March 30 , telegraphy across space, by Prof. Silvanus P. Thomp- 